\title{
Biblioteket vejleder online
}

\author{
Best practice article
}

\section{Pernille Holm Lindhardt}

Det Kgl. Bibliotek - Aarhus / AU Library

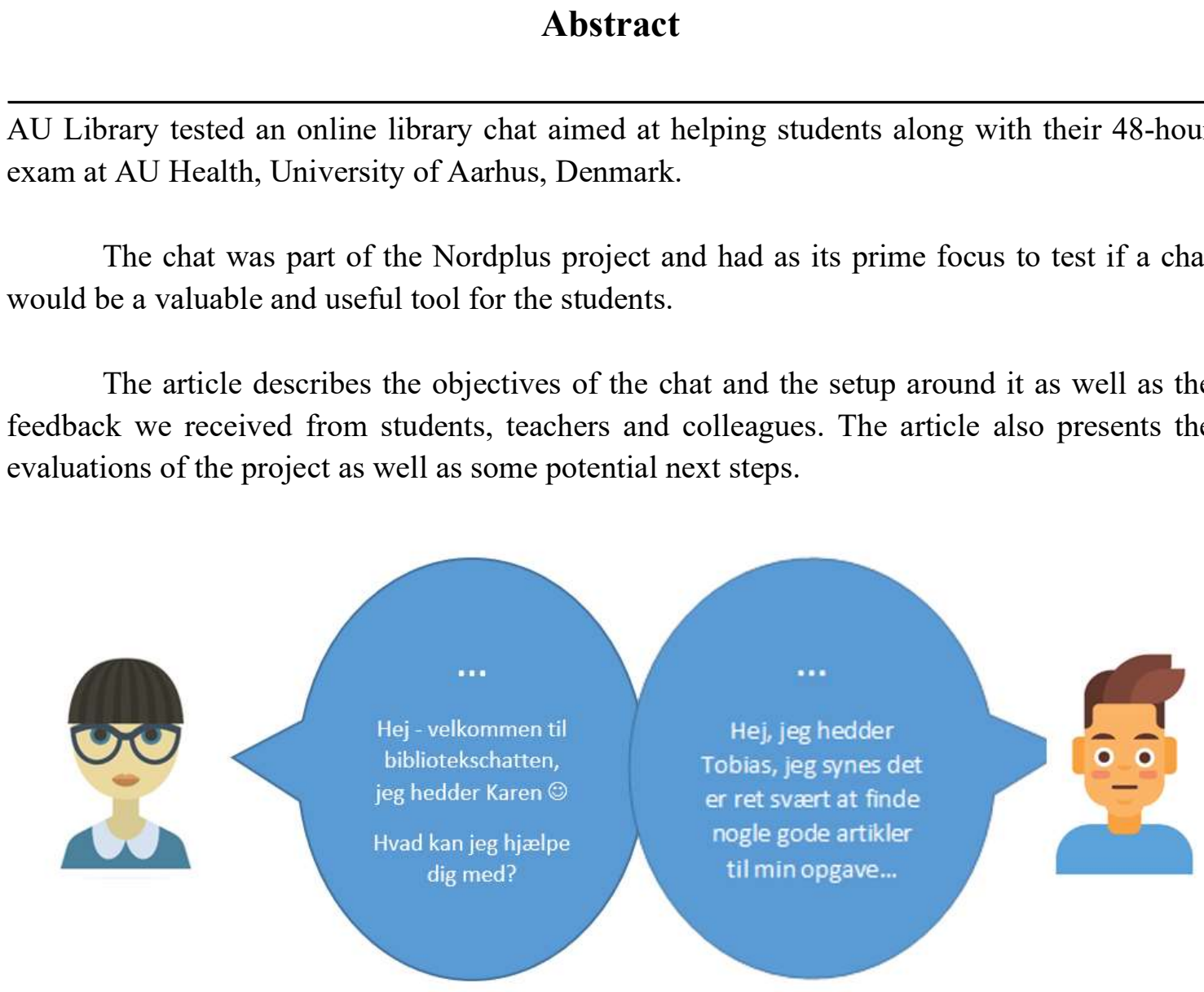

Keywords: online chat, eksamensopgave, studerende, bibliotek, vejledning

\footnotetext{
*Contact:

e-mail:phl@kb.dk
}

Nordic Journal of Information Literacy in Higher Education, 2020. @2020 Pernille Holm Lindhardt 


\section{Indledning}

AU Library er projektpartner i Nordplus-projektet: Udvikling af det digitale universitetsbibliotek. I vores lokale AU Library delprojekt i Nordplus har jeg afprøvet en online biblioteksfaglig chat ud mod en gruppe medicinstuderende. Projektet blev gennemført i samarbejde med bibliotekskolleger fra AU Library Sundhedsvidenskab i Aarhus.

Afsættet for vores delprojekt var to primære spørgsmål:

$>$ At undersøge potentialet $i$ en online chat - om en online kanal til biblioteket giver vores studerende oplevelsen af, at biblioteket er lige ved hånden - tæt på, tilgængeligt og synligt - selv når de ikke befinder sig på universitetets campus eller i nærheden af biblioteket?

$>\mathrm{Om}$ en online chat - som e-læringsværktøj - kan styrke de studerendes informationskompetence, faglighed og selvstændige opgaveløsning?

AU Library har i sin strategi stort fokus på relevante områder, hvor vi med fordel kan udvikle vores services ud mod bibliotekets målgrupper og brugere: Undervisere, forskere og studerende. Biblioteket er opmærksom på at være en nærværende og synlig samarbejdspartner for Aarhus Universitet (AU). Det er vigtigt, at vi udvikler bibliotekets pædagogiske tilgang til de studerende på AU, så vi møder dem, der hvor de har et behov for biblioteksfaglig vejledning og studiestøtte. På AU Library Sundhedsvidenskab besluttede vi at pilotteste potentialet i en online biblioteksfaglig chat målrettet en gruppe studerende i forbindelse med deres 48-timers eksamensopgave. Vores projektoplæg tog udgangspunkt $i$ at afprøve om en online chat kan fungere som:

- En biblioteksfaglig "livline"

- Hurtig og uformel kontakt til biblioteket

- Mulighed for at løse opgaver og faglige spørgsmål sammen med det biblioteksfaglige personale ved behov

- Mulighed for at få relevant faglig hjælp til selvhjulpen opgaveløsning

Undervejs i projektforløbet har vi i de forskellige faser inddraget kolleger, undervisere og studerende for sparring, udvikling, samskabelse / co-creation, feedback og evaluering.

\section{Erfaringer og læring fra Lektier Online}

Pilotforsøget tager afsæt i tidligere projekterfaringer med aktiv og dialogbaseret læring i et virtuelt læringsrum fra det nationale danske projekt "Lektier Online", som blev drevet af Statsbiblioteket (nu Det Kgl. Bibliotek - Aarhus) fra 2010 - 2016. Projektet udviklede online lektiehjælp til et virtuelt læringsrum (Lindhardt \& Hofmeister, 2016; Ravden \& Hofmeister, 2016). Lektier Online-projektet havde som sit mål at skabe et virtuelt rum for læring for elever i den danske grundskole og på en række gymnasiale uddannelser. Studerende, rekrutteret fra en række universitetsuddannelser, fungerede som lektiehjælpere. Lektier Online gav via en online læringsplatform mulighed for at elever kunne logge sig på og via chat, lyd og video få faglig 11 støtte fra projektets lektiehjælpere (Lindhardt \& Hofmeister, 2016; Ravden \& Hofmeister, 2016). 
I Nordplus-projektet greb vi muligheden for at afprøve om erfaringer fra Lektier Online kunne anvendes $\mathrm{i}$ en biblioteksfaglig kontekst og således anvendes til at udvikle universitetsbibliotekets kontaktflade til de studerende. Vores mål var at afprøve et virtuelt biblioteksfagligt rum, en online kommunikationskanal til biblioteket, som de studerende logger sig på og dermed får adgang til biblioteksfaglig hjælp og ressourcer uafhængigt af, hvor de befinder sig - hjemme, på campus eller et helt tredje sted.

I tilrettelæggelse af pilotprojektet blev der trukket på erfaringer fra Lektier Online (Lindhardt \& Hofmeister, 2016; Ravden \& Hofmeister, 2016). Både praksis og forskning i Lektier Online havde fokus på selve interaktionen mellem elev og lektiehjælper i det virtuelle rum. Altså at undersøge, hvordan det fungerede at bruge et virtuelt rum som læringsværktøj, hvordan forløb kommunikationen i læringsrummet og hvilke implikationer var der overordnet i det online set-up med chat, lyd og video som kommunikationsformer (Dohn, Degnebolig, Lindhardt \& Lund, 2016).

\section{Bibliotekschatten}

I Det Kgl. Bibliotek / AU Library findes digitale kanaler, hvor brugerne kan kontakte biblioteket, primært i forhold til kortere, praktiske spørgsmål som fx åbningstider eller adgang til materialer. Aarhus Universitet bruger BlackBoard som LMS og systemet indeholder muligheder for at anvende online, virtuelle læringsrum. Fx når de studerende deltager $\mathrm{i}$ fjernundervisning eller bruger forskellige online collaborative fora $\mathrm{i}$ forbindelse med undervisning eller studiegrupper.

Vores delprojekt tog fat på at afprøve en online synkron biblioteksfaglig vejledningschat via Aarhus Universitets LMS. Altså en online, live vejledningsmulighed, der tager udgangspunkt i en konkret læringskontekst, hvor de studerende kan have brug for at få hjælp og vejledning til at søge materialer - $\mathrm{i}$ dette tilfælde afgrænset til en specifik eksamensopgave.

Vi valgte at bruge Adobe Connect, der er integreret i Aarhus Universitets LMS BlackBoard for at anvende en kanal, der ligger i et sikkert, tilgængeligt system, som de studerende kender og som er en integreret del af deres studier på AU.

$\mathrm{Vi}$ afprøvede vores online biblioteksfaglige chat to gange ud mod to forskellige hold medicinstuderende på 5. semester, der skulle aflevere en 48-timers eksamensopgave i faget "Miljø og arbejdsmedicin" i hhv. efteråret 2017 og forårssemesteret 2018. Vores bibliotekschat var placeret i kendte rammer på AUs LMS, tilgængelig i almindelig åbningstid, og rollerne $\mathrm{i}$ det online møde var i overvejende grad de samme som i det fysiske møde; de studerende henvender sig med biblioteksfaglige spørgsmål og forventer vejledning af det faglige personale.

Begge parter kun kunne kommunikere via chat. Vi fravalgte billede og lyd for at gøre det tekniske setup så enkelt som muligt. Video og lyd gør det tekniske setup mere usikkert og erfaringer fra Lektier Online viser, at en del brugere foretrækker chat alene (Lindhardt \& Hofmeister, 2016; Ravden \& Hofmeister, 2016).

Ved brug af chat som eneste kommunikationsværktøj er der brug for at være særligt opmærksom på forventningsafstemning, hvordan og hvad der kommunikeres skriftligt og hvilke andre ressourcer deltagerne har adgang til og anvender samtidigt, men som ikke er synlige for begge parter og hvor vigtige informationer og "mellemregninger" således kan gå tabt (Dohn et al., 2016). Når man kommunikerer via chat, uden billede eller lyd, der kan 
understøtte og hjælpe kommunikationen på vej, kræver det stor opmærksomhed på, hvordan man formulerer sig og hvor præcis og tydelig man er, når man chatter. Det er vanskeligt at afgøre, hvordan den elev, du kommunikerer med, modtager det, du skriver i en chat og om det, der skrives, forstås og omsættes til brugbar viden (Lindhardt \& Hofmeister, 2016; Ravden \& Hofmeister, 2016).

Den erfaring gav anledning til især at være opmærksomme på, hvordan interaktionen mellem de studerende og mine kolleger forløb. Ingen af mine kolleger havde erfaring med at chatte med de studerende inden vores projekt. Frem mod afprøvningen af vores biblioteksfaglige chat fokuserede vi derfor på to vigtige elementer: For det første at forberede projektgruppen på at bemande chatten i forhold til online kommunikation og teknik. Og for det andet at få information ud til de relevante undervisere og de studerende i målgruppen.

$\mathrm{Vi}$ udviklede forskellige typer materialer op til afprøvningen - bl.a. en intern kommunikationsguide med fokus på, hvad man skal være opmærksom på ved online kommunikation. Herunder opmærksomhed på forventningsafstemning og tydelig kommunikation. Vi testede det praktiske set-up, herunder Adobe Connect conference-systemet, vi lavede vagtplanlægning og afprøvede chatten internt, inden vi gik i luften. I chattens åbningstid havde én kollega chat-vagten og en anden kollega var back-up. Inden afprøvningen lavede vi introduktioner på de aktuelle hold for de studerende, så de fik information om chatten i perioden op til, at de fik deres eksamensopgave udleveret.

I vores åbningstid indsamlede vi "chat-trådene", så vi efterfølgende havde mulighed for at kunne se på indhold og forløb af kommunikationen med det fokus at analysere, hvordan forløbet havde været og om vi kunne få øje på, hvordan vores kommunikation med brugerne havde fungeret.

Vi markedsførte chatten på de biblioteksfaglige kurser, som de studerende deltog $\mathrm{i}$ inden deres eksamen og postede info i deres lukkede AU Facebook-grupper. Vi orienterede også deres undervisere om vores chat og bad dem nævne projektet over for de studerende. Op til selve åbningstiden postede vi reminders i deres facebook-grupper for at minde dem om muligheden for at bruge vores chat.

Et tredje element, som vi brugte en del tid på, var den efterfølgende evaluering af pilotforsøget med både studerende, undervisere og kolleger. Det handler artiklens næste afsnit om.

\section{Evaluering og feedback på bibliotekschat-projektet}

I Nordplus projektet har vi arbejdet specifikt med evalueringsformer i forhold til hvilke metoder, der er relevante og skaber værdi ind i vores projekt. I vores AU Library delprojekt med bibliotekschatten afprøvede vi forskellige typer af evalueringsformer både eksternt og internt.

Overordnet brugte vi både kvantitative og kvalitative evalueringsmetoder i form af surveys og interviews. Vi evaluerede både før, under og efter afprøvningen af vores chat - og vi evaluerede både i forhold til vores målgruppe, altså de studerende, men inddrog også deres fagundervisere og vores bibliotekskolleger. Vi evaluerede også forløbet internt i projektgruppen. 
Vores primære spørgsmål var at få belyst om de studerende, underviserne og kollegerne oplevede bibliotekschatten som et relevant værktøj og en relevant og brugbar kanal til biblioteket.

Nedenfor kommer en oversigt over vores evalueringsprocesser samt eksempler på de svar, vi fik ind:

Tabel 1.

Survey til de studerende via AU Facebook-gruppe. Adspurgte er studerende fra semesteret før vores pilotprojekt, som altså ikke havde tilbud om chat.

\begin{tabular}{|l|l|l|l|}
\hline Maj $2017 \quad$ N=38 & JA & NEJ & MÅSKE \\
\hline Kan du forestille dig at stille spørsmål via en bibliotekschat? & 24 & 1 & 11 \\
\hline $\begin{array}{l}\text { Kan en bib-chat være et relevant værktøj i forbindelse med 48 } \\
\text { timers eksamensopgave i miljø- og arbejdsmedicin? }\end{array}$ & 28 & 1 & 6 \\
\hline
\end{tabular}

Tabel 2.

Survey til målgruppen - dvs. den gruppe medicinstuderende, som vi tilbød mulighed for chat. Brugere og ikke-brugere. Vi havde 11 unikke brugere igennem $i$ chattens åbningstid.

\begin{tabular}{|l|l|}
\hline Oktober $\mathbf{2 0 1 7} \mathbf{N}=\mathbf{4 3}$ & Antal \\
\hline Har brugt chatten & 8 \\
\hline Har ikke brugt chatten & 35 \\
\hline Vurderer at chatten er meget relevant & 22 \\
\hline Vurderer at chatten er relevant & 14 \\
\hline Vurderer at chatten ikke er relevant & 7 \\
\hline Studerende der ikke havde brugt chatten svarede uddybende: & Antal \\
\hline Fordi de ikke havde haft brug for det & 43 \\
\hline Det kunne være relevant for dem en anden gang & 39 \\
\hline
\end{tabular}


Tabel 3.

Survey til målgruppen - $d v$ s. den gruppe medicinstuderende, som vi har tilbudt mulighed for chat. Brugere og ikke-brugere. Vi havde 7 unikke brugere igennem i chattens åbningstid.

\begin{tabular}{|c|c|}
\hline $\mathbf{N}=\mathbf{3 3}$ & Antal \\
\hline Har brugt chatten & 6 \\
\hline Har ikke brugt chatten & 27 \\
\hline Vurderer at chatten er meget relevant & 9 \\
\hline Vurderer at chatten er relevant & 9 \\
\hline Vurderer at chatten ikke er relevant & 15 \\
\hline Studerende der ikke havde brugt chatten svarede uddybende: & Antal \\
\hline Fordi de ikke havde haft brug for det & 31 \\
\hline Det kunne være relevant for dem en anden gang & 30 \\
\hline
\end{tabular}

\section{BEMARK:}

Fra bibliotekschatten var i luften i uge 42, 2017 til umiddelbart inden vi skulle afprøve chatten igen i uge 12, 2018 skete der fra AUs side en ændring i eksamenskravene til den 48 timers eksamensopgave i miljø- og arbejdsmedicin, som fjernede kravet om, at de studerende skulle søge og inddrage supplerende artikler i deres eksamensbesvarelse.

Dermed ændrede de studerendes behov for at få biblioteksfaglig hjælp sig også, hvilket vi vurderer - når vi sammenholder med de studerendes evalueringer - afspejles $i$ antal og indhold af henvendelser i uge 12, 2018.

Vi bad i vores surveys (uge 42 og uge 12) brugerne give os feedback på tilbuddet om en chat. Vi skrev: "Gode råd til os: Hvis du kunne bestemme - hvad kunne vi gøre bedre eller anderledes næste gang?"

Her kommer et par eksempler, som jeg har vurderet afspejler bredden $\mathrm{i}$ de tilbagemeldinger, vi fik:

\section{Brugerfeedback, uge 42, 2017:}

Jeg havde ikke brug for chatten, da kurset i litteratursøgning var tilstrækkeligt for mig - men det var rart at have muligheden, hvis der var noget man blev i tvivl om ift. artiklerne.

Det var virkeligt super! Fik hurtig og rigtig relevant hjælp med at finde en bog af Birgit! :-)

Der sparede jeg lige en times arbejde med at køre ind til VAB og hjem igen. Tak 
Jeg var lidt i tvivl om præcis hvilken type hjælp man kunne hente fra chatten. Eks. om hvor specifikt $\mathrm{i}$ ville hjælpe med at finde en bestemt artikel

Jeg synes det er en rigtig god mulighed for os, selvom jeg ikke brugte det

Det er ikke noget råd, men syntes bare lige jeg ville sige at det har været et fantastisk godt tilbud og med gode hurtige svar! Tusind tak for det! :-)

Jeg vil lige så gerne finde en bibliotekar og snakke face-face to med.

Måske konkretisere, hvad i kunne bruges til.

Rigtig dejligt tilbud, som jeg desværre ikke fik benyttet :)

Mets relevant hvis det var i en periode hvor man ikke havde et tidspress, f.eks. ifm bachelor, hvor man så eks. kunne træffer jer på chatten i bestemte tidsrum på ugen.

\section{Brugerfeedback, uge 12, 2018:}

Lyd, billede, fælles tavle

Vi fik at vide, at det ikke længere var nødvendigt at finde suppelerende litteratur, hvorfor jeg ikke havde brug for det. Havde det stadig været et krav, så kunne jeg meget vel have benyttet mig af det

Da der ikke længere er et krav at man selv skal finde artikler, så tror jeg ikke at der er ret mange der har brug for hjælpen, men jeg er sikker på at det er en virkelig god hjælp til fx bachelor.

Det var rigtig godt!

Tilbuddet var ikke relevant, idet vi ikke længere behøvede søge litteratur på egen hånd. Dog godt tilbud, hvis dette var et krav.

Fordi det ikke længere er et krav at de studerende selv finder litteratur, er det måske lidt overflødigt her - men i andre sammenhænge er det super relevant!

Måske mere relevant i forhold til bachelor, i og med vi ikke selv skulle finde litteratur var behovet ikke så stort i denne omgang :)

\section{Brugerfeedback: Implikationer, indsigter, analytiske pointer}

Fra brugerne fik vi via de to surveys et indblik i, at de syntes, at en chat kan være brugbar, er en god mulighed og er et rigtig godt tilbud, men at tilbuddets art kan gøres tydeligere og mere synligt og måske kan anvendes i andre studie-kontekster. Brugerne udtrykte tilfredshed med brugbar og relevant hjælp, der hjalp dem videre og sparede dem tid i den konkrete afprøvning af chat. Om kanalen styrker deres informationskompetencer og selvstændighed i opgaveløsning vil kræve en bredere afprøvning af chat som e-lærings-værktøj.

\section{Kollega-feedback, uge 42, 2017}

Her kommer et par eksempler fra vores survey, som vi brugte som afsæt til en intern drøftelse af, hvordan kollegaer havde oplevet at skulle bemande og give vejledning online på chat og om de anser chat som et relevant værktøj:

Jeg mangler lidt en måske-mulighed ;-). Jeg synes ikke, at et generelt tilbud om chat er relevant, fordi det vil koste for mange personaleressourcer i forhold til udbyttet. Men som 
supplement i specielle situationer - fx 48-timersopgaven - fungerer det okay. Den egner sig fint til hurtigt at få løst et simpelt problem: fx var der flere, der ikke kunne få adgang til artiklerne, fordi de ikke var gået den rigtige vej ind i databaserne.

De spørgsmål vi fik, var relevante. Spørgerne forstod at skelne mellem biblioteksfaglige spørgsmål og spørgsmål til faget

Som nævnt ovenfor vil det være godt at overveje hvordan vagtdækningen bedst tilrettelægges når chatten har lange perioder med ingen aktivitet (men også enkelte med mere intensiv aktivitet). Det ville også være godt hvis der kunne udvikles på den tekniske løsning. De studerendes præference for private chattråde gjorde det svært for de andre hosts at følge med i hvor meget aktivitet der var og det gjorde overlevering mellem vagter mindre sømløs.

\section{Kollega-feedback, uge 12, 2018}

Vi er tilgængelige for dem - også på distancen.

Godt at vi er tilgængelige også for studerende, der ikke sidder i bygningen

Det var relevant $\mathrm{i}$ forhold til den gamle type opgave, med det ændrede regelsæt så er jeg i

tvivl.

Umiddelbart synes jeg, at chat er et godt tilbud og det giver go' mening i forhold til 24-timers opgaven. Meningen forsvinder dog lidt, hvis de studerende ikke skal finde ekstra litteratur til deres opgave. Jeg synes ikke, der virker som om der er behov for en fast chat-funktion, hvis man ser på antallet af spørgsmål, der er modtaget

Måske bliver tilbuddet om chat-funktionen ikke brugt meget fordi det kun er tilgængeligt en eller to gange om året. Men en fast chat-funktion kræver også at man 'får en vagt', og det lægger beslag på vores tid - ud over den faste vagt i biblioteket. Det er ærgeligt, at mail ikke lige er de studerendes 'thing', for det vil give lige så god mening at slå et ekstra slag for den. Et andet chat-software ville være rart. Det vil være fint at teste med en anden målgruppe.

\section{Kollega-feedback: Implikationer, indsigter, analytiske pointer}

Kollegerne i projektgruppen gav udtryk for overvejelser for og i mod chat som et permanent tilbud set ifht forbrug af personaleressourcer ved vagtdækning af en chat. De fremhævede også, at det tekniske set-up kræver udvikling. I forhold til chat som en brugbar kanal til de studerende, oplevede de, at det var konstruktivt at være tilgængelige og at kunne hjælpe de studerende på afstand og at de spørgsmål, de fik ind var relevante. At det kunne være fint at teste et chat-tilbud bredere - ud mod andre målgrupper og kontekster.

\section{AU fagunderviser feedback, forår 2018}

Som den tredje vinkel i læringstrekanten: Studerende - Bibliotek - Underviser, sendte jeg også et survey til AU underviserne - via bibliotekets underviserkontakt - efter anden afprøvning af vores chat. Hun videresendte i sit netværk og her svarede 8 undervisere, 1 ph.d. studerende og en sekretær tilbage.

Nedenfor ses en oversigt over deres feedback på vores chat-projekt: 
Vi spurgte:

"Vurderer du, at en online bibliotekschat er en relevant kanal i forhold til de studerende?"

Alle svarede ja.

Vi spurgte derefter om følgende:

"Særligt i hvilken sammenhæng?" Her kommer de svar, vi fik ind:

- For at hjælpe dem med de tekniske og metodiske udfordringer i at citere rigtig og hvordan man finder relevante kilder.

- Ved litteratursøgning og eventuelle problemstillinger der opstår ved litteratursøgninge i forskellige databaser. Hvordan trunkerer man? Hvor findes der en liste med emneord? Hvor kan søgningen gøres mere præscis foreksempel på bestemte typer studiedesigns?

- Når de skal søge litteratur til projekter/artikler

- reference søgning

- I forbindelse med eksamen, specielt før så relevante spørgsmål bliver stillet det rigtige sted fra starten

- Forskning

Herefter spurgte vi:

"Vurderer du som underviser, at en chat som pædagogisk værktøj kan understøtte de studerendes læreprocesser?” Af 10 respondenter svarede 8 ja og 2 svarede nej.

Vi bad dem videre om at uddybe og her kommer de svar, vi fik ind:

- Især hjælp til selvhjælp som det blev tilbudt nu er rigtig vigtig for dem også i henblik til deres bacheloropgave og senere opgaveskrivning

- Når de studerende får gennemgået hvordan en database fungerer så får de en basal viden om muligheder, men det er først når de skal bruge det at denne læring reelt bliver omsat. Det er ofte også først i forbindelse med et konkret eksempel/eksamensopgave at de bliver bevidst om, hvad de ikke ved, og har brug for at spørge nogen om hjælp.

\section{AU fagunderviser-feedback: Implikationer, indsigter, analytiske pointer}

Underviserne var meget entydigt positive. De lagde vægt på relevansen af den biblioteksfaglige hjælp, som de studerende kan få adgang til via vores chat-tilbud. I forhold til at vurdere chat som et relevant pædagogisk værktøj, fremhævede underviserne vores "hjælp til selvhjælp" tilgang som brugbar. Og at de studerende kan få biblioteksfaglig hjælp, når de skal afprøve deres informationskompetencer i en konkret opgave-situation.

\section{Hvad lærte vi?}

Vores udgangspunkt for AU Library delprojektet var at undersøge om en online biblioteksfaglig chat er relevant som værktøj og kanal til biblioteket. På baggrund af de to test-udrulninger har vi sammenfattet viden, erfaringer og feedback i følgende hovedpunkter: 
- Projektgruppen vurderer, at vores pilot-tilbud om biblioteksfaglig chat grundlæggende fungerede og løste sin opgave: Overordnet fik chat-vagterne hjulpet de fleste brugere godt videre i forhold til de konkrete henvendelser.

- De studerende syntes overordnet, at en bibliotekschat er et godt initiativ og et relevant tilbud og værktøj, hvis ikke i denne konkrete sammenhæng - 48 timers miljø-og arbejdsmedicinopgaven - så på et andet tidspunkt i deres studieforløb. Fx i bachelor-forløbet.

I vores interview har vores kursusansvarlige AU underviser tilkendegivet at vores chattilbud er et "positivt", "vigtigt" tiltag og "vigtig støtte". Underviseren kunne notere færre henvendelser fra de studerende i opgaveperioden - som vagthavende faglig underviser.

Adspurgte AU undervisere har meldt tilbage, at chat er en relevant kanal, både $\mathrm{i}$ litteratursøgning og citationspraksis og at "hjælp til selvhjælp" er vigtig - fx i bachelorforløbet.

I planlægning af et chat-tilbud er det vigtigt at overveje det tekniske set-up, målgrupper, skala og indhold for chatten. Det tager tid at udvikle format og koncept og at forberede nye kolleger på at løse opgaven. Det kræver øvelse og opmærksomhed på rollen og kommunikationsformen at bemande chatten. Vi brugte ikke video eller lyd, men det kunne man overveje at tilbyde brugerne, da det på nogen måder letter kommunikationen. Men der er også brugere, som netop vil foretrække chatten, fordi den tillader brugeren at kunne være mere anonym. Adobe Connect er ikke den optimale tekniske løsning, brugerfladen opleves som "uhandy" fx i forhold til at tilbyde de studerende privat chat og "del skærm" funktion.

Bemanding og åbningstider skal nøje overvejes og målrettes for at undgå lange vagter og sikre fleksibilitet og relevans.

Adspurgte studerende har givet udtryk for, at de er meget glade for at komme i biblioteket, få face-to-face vejledning og deltage i de fysiske bibliotekskurser. Chat er ikke nødvendigvis en løsning, der appellerer til alle, men kan være et brugbart supplement og løsning for nogle af bibliotekets brugere og i særlige kontekster.

Mine kolleger der stod for at bemande chatten havde en positiv, konstruktiv oplevelse af at være tilgængelige for de brugere, som benyttede vores tilbud om online biblioteksfaglig sparring. Det kan være svært helt at afgøre, om vi når ud til nye brugere, der ellers ikke ville have fået hjælp, men det vil naturligvis også være en vigtig positiv effekt af tilbuddet.

Markedsføring og formidling af tilbuddet skal være tydelig og synlig: Hvornår og til hvad kan chatten bruges.

Vi kunne godt have hjulpet flere studerende i vores åbningstid, men antallet af sessioner gjorde os i stand til få afprøvet forskellige scenarier og problemstillinger i forhold til at give online vejledning til brugere med forskellige behov. Erfaringerne er værdifulde i forhold til en mulig fremtidig afprøvning.

På baggrund af de surveys vi har fået ind, har vi internt i projektgruppen drøftet feedback og brugt tid på at undersøge og analysere kommunikation i chatten, lave udkast til brugerprofiler og brugerrejser i projektet og har således samlet værdifulde erfaringer, som kan bruges, hvis der bliver mulighed for at afprøve chat som kanal til de studerende i en anden kontekst.

Vores surveys har givet et vist indblik i både hvorfor de studerende i målgruppen har brugt os og hvorfor de ikke har brugt os i pilotfasen. Dog vil det være godt at udvikle dialogen 
med de studerende om adfærd og behov og ligeledes udvikle kontakt, dialog og adgang til undervisere, så vi sikrer relevansen af en chat og udnytter potentialet.

\section{Perspektivering}

Vi har i projektet identificeret en række spørgsmål, der kan danne udgangspunkt for videreudvikling:

$>$ Hvordan får vi mere information om de studerendes adfærd og behov?

$>$ Hvad kan / skal vi udvikle i chat-tilbuddet? Hvad er der behov for? Hvordan gør vi det bedst?

$>$ Hvordan designer vi et fleksibelt chat-tilbud, der kan tilrettes forskellige kontekster og behov?

$>$ Hvordan integrerer vi chat i den daglige værktøjskasse?

> Hvordan sikrer vi, at vi tilrettelægger vores chat-tilbud, så vi styrker læringstrekanten?

\section{Konklusion}

På baggrund af vores to forsøg med chat vurderer projektgruppen, at der er et potentiale $\mathrm{i}$ at tilbyde de studerende en mulighed for at kunne tilgå biblioteket via en online kanal som fx en chat-funktion. Det har været værdifuldt at afprøve denne kanal til biblioteket. Den kræver et brugbart teknologisk set-up og den kræver, at vi er opmærksomme på brugernes behov og kontekst.

$\mathrm{Vi}$ vurderer ikke, at en chat skal ses som en mulig erstatning for det fysiske biblioteksrum eller de fysiske kurser og den personlige face-to-face vejledning, men som en supplerende kanal, et e-læringsværktøj, der fx målrettes en særlig kontekst, opgaver, studie- og eksamensperioder, hvor en chat kan understøtte de studerendes læreprocesser.

Vores analyser viser, at der er potentiale $i$ at afprøve en online biblioteksfaglig chat $\mathrm{i}$ nye kontekster - særligt ud mod de brugergrupper, som bruger biblioteket på afstand - og hvor det vil være brugbart at have mulighed for at få vejledning online.

Vi har i et aktuelt udviklingsprojekt undersøgt brugernes møde med AU Library på Aarhus Universitetshospital i Skejby, hvor en del af vores brugere er ansatte og studerende, der arbejder på afstand af biblioteket og hvor biblioteket ikke fysisk er til stede hver dag. Her kunne det være relevant at undersøge effekten af at tilbyde en online biblioteksfaglig kanal til bibliotekets brugere.

\section{Referencer}

Dohn, N.B., Degnebolig, H.S., Lindhardt, P.H. \& Lund, K. (2016) Lektier Online - didaktisk design af et uformelt online læringsrum? Laering og Medier, 9(15). Hentet fra https://tidsskrift.dk/lom/article/view/23363/20716

Lindhardt, P.H. \& Hofmeister, E. (2016). Slutrapport: Lektier Online GYM 2014-2016. Upubliceret.

Ravden, N. \& Hofmeister,E. (2016). Slutrapport: Lektier Online til folkeskolen 2015-2016. Upubliceret. 